\title{
The Role of Sulfadiazine for the Treatment of Refractory Intracranial Infection
}

\section{Dirençli Intrakranial Enfeksiyon Tedavisinde Sülfodiazin’in Rolii}

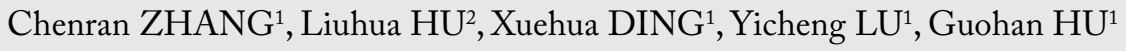 \\ ${ }^{1}$ Second Military Medical University, Changzheng Hospital, Department of Neurosurgery, Shanghai, China \\ ${ }^{2}$ Shanghai Jiao Tong University, Ren Ji Hospital, School of Medicine, Department of Cardiology, Shanghai, China
}

Corresponding Author: Guohan HU / E-mail: huguohan@163.com

\begin{abstract}
AIM: Sulfadiazine (SD) is a classic antibiotic for intracranial infection. Due to the medical market policy, SD has not been chosen as an essential drug in all the hospitals in China. However, its therapeutic effect is definite and cannot be substituted. The aim of this study was to evaluate the therapeutic and economic value of SD compared to other popular antibiotics in patients with refractory intracranial infection.

MATERIAL and METHODS: A retrospective single-center study was performed from January 2011 until December 2012. Thirteen patients diagnosed with refractory intracranial infection were treated with SD. The clinical effects were reviewed.

RESULTS: Treatment was successful for 12 of the patients (cure rate=92.3\%). One patient died of secondary epilepsy, respiratory complications, and multiple organ failure. Only one patient was allergic to SD, and there were no drug-related liver or kidney side effects.

CONCLUSION: SD is a safe, effective, and economical antibiotic, and is used by our neurosurgical department. It should be offered as an option for the patients with refractory intracranial infection, especially for patients with lower ability to pay.
\end{abstract}

KEYWORDS: Sulfadiazine, Refractory intracranial infection, Posterior fossa approach, Cerebrospinal fluid leakage

öz

AMAÇ: Sülfodiazin (SD) intrakranial enfeksiyonlar için klasik bir antibiyotiktir. Tıbbi pazar politikasından dolayı SD Çin'de tüm hastanelerde temel ilaç olarak tercih edilmez. Ancak onun tedavi edici etkisi kesin ve tartışılmazdır. Çalışmanın amacı SD’nin dirençli intrakranial enfeksiyonu olan hastalarda tedavi edici etkisini araştırmak ve bunu diğer popüler antibiyotiklerle karşılaştırmaktır.

YÖNTEM ve GEREÇLER: Bu tek merkezli retrospektif çalışma Ocak 2011 ile Aralık 2012 arasında gerçekleştirildi. Onüç hastada dirençli intrakranial enfeksiyon tanısı konuldu ve SD ile tedavi edildi. Klinik etkileri gözden geçirildi.

BULGULAR: Hastaların 12'sinde tedavi başarılı oldu (Kür oranı=\%92,3). Bir hasta sekonder epilepsi, solunumsal komplikasyonlar ve çoklu organ yetmezliğinden dolayı kaybedildi. Sadece bir hastada SD'e karşı allerji tesbit edildi ve ilaca bağlı karaciğer veya böbrek yan etkileri görülmedi. SONUÇ: SD güvenli, etkili ve ekonomik bir antibiyotiktir ve bizim nöroşirürji bölümümüzde kullanılmaktadır. Dirençli intrakranial enfeksiyonu olan, özellikle düşük gelir düzeyli hastalarda bir seçenek olarak kullanılmalıdır.

ANAHTAR SÖZCÜKLER: Sülfodiazin, Dirençli intrakranial enfeksiyon, Posterior fossa yaklaşımı, Beyin-omurilik sıvısı kaçağı

\section{INTRODUCTION}

Intracranial infection is a common postoperative complication in neurosurgical patients. It is a significant problem worldwide and results in substantial morbidity/mortality if not treated quickly and vigorously (6).

Significantly varied rates of intracranial infection have been reported, ranging from 0.72 to $>8 \%(7,11)$, depending on antibiotic prophylaxis, diverse periods in which the surveys were conducted, as well as different countries in which the studies were conducted. Despite a dramatic increase in technological advancement in neurosurgical and postoperative care, the intracranial infection rate following neurosurgeries has not decreased as much as expected in recent decades. Indeed, it has been suggested that the actual incidence of intracranial infection $s$ is even higher than that reported (9). Although many methods have been used to prevent these infections, the rate of occurrence is still very high.

Sulfadiazine (SD) used to be a classical antibiotic for treatment of intracranial infections in China and worldwide, with a broad antibiogram. It is effective for most gram-positive and gramnegative bacterial infections. However, nowadays the use of SD is mainly confined to treatment of partial-thickness and mid-dermal burn, and toxoplasmic encephalitis $(1,3,4,10,14)$.

A good preoperative assessment, a successful surgery, effective postoperative management, and most importantly, an effective and economical antibiotic are necessary for the prevention of intracranial infection. We retrospectively reviewed 13 cases of refractory intracranial infection that were treated with SD. Information on the clinical data, the 
therapeutic results, and the side effects were available for all of the patients. We defined refractory intracranial infection as the inability to control infection after routine antiinflammatory treatments, including empirical antimicrobial therapy, external ventricular drainage, and/or cisterna cerebellomedullaris drainage.

\section{PATIENTS and METHODS}

Thirteen patients with intracranial lesions were treated surgically between January 2011 and December 2012 at the Department of Neurosurgery, Shanghai Changzheng Hospital, China. Every patient developed refractory intracranial infection after surgery. Demographic data, data on infectious predisposing factors, anatomical location of the lesion, and microbiology results were obtained from electronic hospital data forms for all of the patients (Table I). The director of our department made the decision to treat the patients with sulfadiazine. This was an observational study and all care was decided by the attending physician with no involvement of the researchers. Written approval was obtained from the ethics committee of Shanghai Second Military Medical University for this study. A written consent in accordance with the ethical committee standards was given to and signed by participating patients (by post or outpatient follow-up). The consent obtained for patients that died was signed by the same clientele as their duration of hospital stay.

\section{Medical Regimen}

As soon as the diagnosis of intracranial infection was confirmed, empirical antimicrobial therapy was initiated.
Our initial empirical antimicrobial therapy included a combination of vancomycin and ceftriaxone. If the infection was not controlled within 3 to 5 days, we chose linezolid and meropenem, or changed to more targeted antibiotics as soon as the results of sensitivity tests were available. At the same time, intrathecal injections of gentamycin (4-8 mg) or vancomycin (20 mg) were given every day. If the intracranial infection was not controlled after these treatments, we treated with SD (sodium).

SD $(0.4 \mathrm{~g} / 2 \mathrm{ml})$ was purchased from the Shanghai Modern "Harson" Pharmacology Company (Shanghai, China). A druguse written consent was signed by patients or their legal guardians. The first dose was $50 \mathrm{mg} / \mathrm{kg}$, followed by 1600 mg IV every 6 h. During treatment, we monitored clinical manifestations, temperature, blood routine test, cerebrospinal fluid (CSF), and, if necessary, modified the dose. The largest dose was $150 \mathrm{mg} / \mathrm{kg}$. Body temperature was usually normal after 3-7 days treatment, and the CSF gradually cleared. A course of SD treatment was 7-20 days, with an average of 15 days. Oral sulfamethoxazole (0.96 g, BID) was then given after the IV treatment. The entire course of antibiotic therapy was 4-8 weeks, depending on the therapeutic response. Infectious disease specialists regularly supervised the treatments.

\section{RESULTS}

The 13 patients were 7 males and 6 females, with an average age of 49.6 years (range 15-69 years). All the patients received external ventricular or lumbar catheters (continuous drainage) before or after the intracranial infection. Some of the causes

Table I: Clinical Data of 13 Patients Treated with SD

\begin{tabular}{|c|c|c|c|}
\hline Case (No) (age/sex) Underlying disease & $\begin{array}{l}\text { Posterior fossa } \\
\text { approach }\end{array}$ & CSF leakage & Pathogen \\
\hline 1- Female, $61 y$, epidermoid cyst in fourth ventricle & yes & & Acinetobacter baumannii \\
\hline 2- Female, 60y, left trigeminal neuralgia & yes & & \\
\hline 3- Male, 49y, SAH, hydrocephalus & & & Stenotrophomonas maltophilia \\
\hline $\begin{array}{l}\text { 4- Male, } 52 \mathrm{y}, \mathrm{SAH} \\
\text { anterior communicating aneurysm }\end{array}$ & & & $\begin{array}{l}\text { Sphingomonas paucimobilis } \\
\text { Pseudomonas fluorescens } \\
\text { fragrant Flavobacterium }\end{array}$ \\
\hline 5- Male, 59y, T10-L2 epidural arachnoid cysts & & yes & Enterobacter cloacae \\
\hline 6- Female, 27y, left acoustic neuroma, & yes & & \\
\hline 7- Male, 55y, left trigeminal neurinoma & yes & yes & Klebsiella pneumoniae \\
\hline 8- Female, 57y, right acoustic neuroma & yes & & Flavobacterium indologenes \\
\hline 9- Male, 69y, pituitary adenoma & & yes & \\
\hline \multicolumn{4}{|l|}{ 10- Male,15y, T3-11 L2-S1 epidural arachnoid cysts } \\
\hline $\begin{array}{l}\text { 11- Female, } 61 y \text {, epidermoid cyst in cerebellum } \\
\text { vermiform }\end{array}$ & yes & & \\
\hline \multicolumn{4}{|l|}{ 12- Female, 41y, PRL pituitary adenoma } \\
\hline $\begin{array}{l}\text { 13- Male, } 40 y, \text { cavernous malformation in lateral } \\
\text { ventricles }\end{array}$ & & & \\
\hline
\end{tabular}

SAH: subarachnoid hemorrhage, CSF: cerebrospinal fluid, y: years, PRL: prolactin. 
of the infections were catheter-related, some were related to the surgery, and some were from CSF leakage through the incision. Treatment was successful for 12 of the patients (cure rate=92.3\%). One patient died of secondary epilepsy, respiratory complications, and multiple organ failure. Only one patient was allergic to SD, and there were no drug-related liver or kidney side effects.

\section{Clinical Manifestation}

Fever is the most obvious symptom, followed by rigor and meningeal irritation. Routine blood tests showed a white blood cell (WBC) count greater than $10 \times 10^{9} / \mathrm{L}$ in all 13 cases, in which 5 cases were greater than $20 \times 10^{9} /$ L. Over $80 \%$ of neutrophilic granulocytes were observed in all cases. All patients received a blood culture if the temperature reached $38.5{ }^{\circ} \mathrm{C}$ or the patients had rigor. However, only one patient had a positive result in a blood culture: Staphylococcus epidermidis.

A CSF examination was performed on all patients, which included examinations of pressure, appearance, biochemistry, culture, and drug sensitivity. The CSF pressure ranged from 250 to $400 \mathrm{~mm} \mathrm{H}_{2} \mathrm{O}$. The appearance was turbid, like rice water, or even with flocculent pus. The WBC count in the CSF was greater than $400 \times 10^{6} / \mathrm{L}$ in 10 cases and equal to $400 \times 10^{6} / \mathrm{L}$ in 3 cases. The biochemistry results of the CSF showed a positive Pandy test. Glu was between 0.1 and $2.0 \mathrm{mM}$. CSF culture and drug sensitivity tests showed that four patients had the same broad spectrum-resistant bacterial infection in at least two successive tests: Acinetobacter baumannii, Stenotrophomonas maltophilia, Flavobacterium indologenes and Klebsiella pneumoniae, respectively. In one patient, a culture of both the lateral ventricle catheter and the CSF yielded Sphingomonas paucimobilis. However, a subsequent CSF culture test yielded positive results for Pseudomonas fluorescens and fragrant Flavobacterium. One case was positive for Enterobacter cloacae, whereas the others were negative.

\section{Illustrative Cases}

One patient was a female, 61 years in age, with a fourth ventricle epidermoid cyst. Her state of consciousness became severely affected on the fifth day after surgery. The head CT scan revealed obstructive hydrocephalus, and emergency external ventricular drainage was performed. A definitive diagnosis of intracranial infection was made on the third day when a high fever developed, which was accompanied by turbid CSF. Continuous external ventricular drainage and anti-inflammation therapy were initiated. The patient then developed status epilepticus. After anti-epileptic therapy, the patient's state of consciousness worsened, so a tracheotomy was performed. She also developed bipolar pneumonia. SD and Sulperazon (cefoperazone + sulbactam) were given, which controlled the intracranial infection and pneumonia. However, the patient died from multiple organ dysfunction syndrome (MODS).

One patient was a male, 55 years in age, with a left trigeminal neurinoma. After surgery, he recovered without complications.
Ten days after surgery, the sutures were removed from the suboccipital incision. The upper part of the incision appeared to be leaking cerebrospinal fluid after a severe cough during the night. The next day, the patient was hyperpyrexic, with a temperature $=40^{\circ} \mathrm{C}$. Vancomycin and ceftriaxone sodium were given, and cisterna cerebellomedullaris drainage was performed. The infection was not controlled, so we changed to SD therapy. Routine blood tests and the CSF returned to normal, but the temperature fluctuated. A test for a fungal infection was negative. A small dose of dexamethasone was added, and the temperature returned to normal.

\section{DISCUSSION}

Dubey et al. (2) reported that CSF leaks were most frequently encountered in $13 \%$ of posterior cranial fossa surgery patients, followed by meningitis (9.2\%) and wound infection (7\%), which are consistent with our findings and other reports (5). In a large scale retrospective survey in Chinese population, Zhan et al. (15) drew the conclusion that CSF leakage, CSF drainage of any kind, subsequent short term surgery, and surgery duration were major risk factors of postoperative intracranial infection, indicating that surgery-focused management might be the most effective way to minimize the risk for central nervous system infection after cranial surgery.

To prevent postoperative infection, our neurosurgical department advocates appropriate use of prophylactic antibiotics. In general, a broad-spectrum antibiotic, usually a second generation cephalosporin, is administered 30 minutes before surgery. If the surgery exceeds 4 hours in length, or the volume of blood loss exceeds $1 \mathrm{~L}$, and additional dose is given. Standard sterile techniques, meticulous wound closure, and proper wound care after surgery also minimize the risk of intracranial infection. When postoperative infection does occur, attention is commonly focused on potential lapses in surgical "sterility".

Evidence suggests that the surgical field is not free of microorganisms (8). Walcott et al. (13) proposed a paradigm shift in the nomenclature of the surgical field from "sterile" to "clean." Continued efforts aimed at optimizing immune capacity and host defenses to combat potential infection are warranted.

SD should be used when routine antibiotics are not effective or when financial considerations are an issue. Not all of China's citizens are covered by health insurance. Different proportions of a patient's cost of hospitalization are reimbursed, and these proportions are lower for patients from rural areas. Therefore, economic factors must be considered when the clinician chooses the therapeutic schedule. Fortunately, SD controls the infection and, at the same time, relieves the economic burden. Table II presents the daily expense for different therapeutic schedules for antibiotics used in our hospital.

Vena et al. (12) reported a unique case of post-neurosurgical meningitis due to methicillin-resistant Staphylococcus epidermidis (MRSE) resistant to linezolid and with reduced susceptibility to glycopeptides, successfully treated with 
Table II: Daily Expense of Different Therapeutic Scheme of Antibiotics

\begin{tabular}{|l|c|c|c|c|}
\hline Antibiotic & Price(RMB) & Daily dose & Expense(RMB) & Total fee(per day)(RMB) \\
\hline Vancomycin & $0.5 \mathrm{~g} / 144$ & $1000 \mathrm{mg}, \mathrm{bid}=2 \mathrm{~g}$ & 576 & \\
\hline Rocephin & $1 \mathrm{~g} / 65.70$ & $2 \mathrm{~g}, \mathrm{bid}=4 \mathrm{~g}$ & 262.8 & 838.8 \\
\hline Linezolid & $0.6 \mathrm{~g} / 453$ & $0.6 \mathrm{~g}, \mathrm{q} 12 \mathrm{~h}=1.2 \mathrm{~g}$ & 906 & 3222 \\
\hline Mepem & $0.5 \mathrm{~g} / 193$ & $2 \mathrm{~g}, \mathrm{q} 8 \mathrm{~h}=6 \mathrm{~g}$ & 2316 & 72 \\
\hline SD & $0.4 \mathrm{~g} / 4.5$ & $1600 \mathrm{mg}, \mathrm{q} 6 \mathrm{~h}=6.4 \mathrm{~g}$ & 72 & 72 \\
\hline
\end{tabular}

RMB: Chinese Yuan

a combination of daptomycin at $10 \mathrm{mg} / \mathrm{kg}$ daily plus trimethoprim/sulfamethoxazole (TMP/SMX). They concluded that combination of high-dose daptomycin plus TMP/SMX is a reasonable option for treatment of meningitis caused by multidrug-resistant S. epidermidis. In our study, four patients had the same broad spectrum-resistant bacterial infection in at least two successive tests, which were all successfully cured by SD.

Due to medical market policy, SD has not been chosen for the essential drug catalog in almost all of the hospitals in China. But, it has a definite therapeutic effect and there are no appropriate substitutes. SD is a classical antibiotic for treatment of intracranial infections. When injected, SD is widely distributed in whole body tissue and humour (e.g., pleural fluid, peritoneal fluid, synovial fluid, aqueous humor). It also penetrates the blood-brain barrier. The drug concentration of SD in CSF is $50 \%$ of that in blood without meningitis. However, the drug concentration increases to $50-80 \%$ with meningitis. It also easily penetrates fetal blood circulation. The elimination half life of SD is 10 hours with normal kidney function and is 34 hours in patients with kidney failure. SD (60-85\%) is discharged in the urine in the form of the drug prototype after 48-72 $\mathrm{h}$. The protein binding rate is $38-48 \%$.

As a result of our experience on SD, we have several recommendations to treat refractory intracranial infections. The initial dose should be large, especially for treatment of cases with a positive CSF culture test. The recommended initial dose is $50 \mathrm{mg} / \mathrm{kg}$, followed by $1600 \mathrm{mg}, \mathrm{q} 6 \mathrm{~h}$, in order to ensure that a sufficient blood drug concentration is achieved after passing blood brain barrier. The course of treatment should be long, and sequential therapy is strongly recommended. SD is a safe, effective, well-tolerated, and classical antibiotic for the treatment of intracranial infection.

\section{ACKNOWLEDGMENTS}

This work was generously supported by Shanghai Municipal Natural Science Foundation (14ZR1413800), Shanghai Municipal Health Bureau Project (201440383) and Foundation for Youths of Changzheng Hospital (2012CZQN05).

\section{REFERENCES}

1. Chirgwin K, Hafner R, Leport C, Remington J, Andersen J, Bosler EM, Roque C, Rajicic N, McAuliffe V, Morlat P, Jayaweera DT, Vilde JL, Luft BJ: Randomized phase II trial of atovaquone with pyrimethamine or sulfadiazine for treatment of toxoplasmic encephalitis in patients with acquired immunodeficiency syndrome: ACTG 237/ANRS 039 Study. AIDS Clinical Trials Group 237/Agence Nationale de Recherche sur le SIDA, Essai 039. Clin Infect Dis 34(9):12431250,2002

2. Dubey A, Sung WS, Shaya $M$, Patwardhan R, Willis B, Smith D, Nanda A: Complications of posterior cranial fossa surgeryan institutional experience of 500 patients. Surg Neurol 72(4):369-375, 2009

3. Genuino GA, Baluyut-Angeles KV, Espiritu AP, Lapitan MC, Buckley BS: Topical petrolatum gel alone versus topical silver sulfadiazine with standard gauze dressings for the treatment of superficial partial thickness burns in adults: A randomized controlled trial. Burns 40(7):1267-1273, 2014

4. Hollinger MA: Toxicological aspects of topical silver pharmaceuticals. Crit Rev Toxicol 26:255-260, 1996

5. Howitz MF, Homøe P:The risk of acquiring bacterial meningitis following surgery in Denmark, 1996-2009: A nationwide retrospective cohort study with emphasis on ear, nose and throat (ENT) and neurosurgery. Epidemiol Infect 142(6):13001309, 2014

6. McClelland $S 3^{\text {rd: }}$ Postoperative intracranial neurosurgery infection rates in North America versus Europe: A systematic analysis. Am J Infect Control 36:570-573, 2008

7. Reichert MC, Medeiros EA, Ferraz FA: Hospital-acquired meningitis in patients undergoing craniotomy: Incidence, evolution, and risk factors. Am J Infect Control 30(3):158-164, 2002

8. Shiono Y, Watanabe K, Hosogane N, Tsuji T, Ishii K, Nakamura M, Toyama Y, Chiba K, Matsumoto M: Sterility of posterior elements of the spine in posterior correction surgery. Spine (Phila Pa 1976) 37:523- 526, 2012

9. Tattevin P, Patrat-Delon S, Le Ho H: Postoperative central nervous system infection after neurosurgical procedures: The bride is too beautiful. Clin Infect Dis 45(9):1248-1249, 2007 
10. Tomasoni LR, Meroni V, Bonfanti C, Bollani L, Lanzarini P, Frusca T, Castelli F: Multidisciplinary approach to congenital Toxoplasma infection: An Italian nationwide survey. New Microbiol 37(3):347-354, 2014

11. Valentini LG, Casali C, Chatenoud L, Chiaffarino F, UbertiFoppa C, Broggi G: Surgical site infections after elective neurosurgery: A survey of 1747 patients. Neurosurgery 62(1):88-95, 2008

12. Vena $A$, Falcone $M$, Comandini $E$, Meledandri $M$, Novelli A, Campanile F, Stefani S, Venditti M: Daptomycin plus trimethoprim/sulfamethoxazole combination therapy in post-neurosurgical meningitis caused by linezolid-resistant Staphylococcus epidermidis. Diagn Microbiol Infect Dis 76(1):99-102, 2013
13. Walcott BP, Redjal N, Coumans JV: Infection following operations on the central nervous system: Deconstructing the myth of the sterile field. Neurosurg Focus 33(5):E8, 2012

14. White RJ, Cutting KF: Interventions to avoid maceration of the skin and wound bed. Br J Nurs 12:1186-1201, 2003

15. Zhan R, Zhu Y, Shen Y, Shen J, Tong Y, Yu H, Wen L: Postoperative central nervous system infections after cranial surgery in China: Incidence, causative agents, and risk factors in 1,470 patients. Eur J Clin Microbiol Infect Dis 33(5):861-866, 2014 